\title{
Interaction of Monocytes with Tumor Cells Coated with Complement with or without Antibody ${ }^{1}$
}

\author{
Howard B. Kessler and Albert F. LoBuglio ${ }^{2}$ \\ Division of Hematology and Oncology, Ohio State University, College of Medicine, \\ Columbus, Ohio 43210 and Simpson Memorial Research Institute, University of \\ Michigan, Ann Arbor, Michigan 48109
}

Received April 25, 1979

\begin{abstract}
Raji, a human B lymphoblastoid cell line has the ability to activate the complement cascade by alternate pathway mechanisms with subsequent fixation of $\mathrm{C} 3$ to receptors on the Raji cell membrane. Using this property, we examined the role that complement plays in mediating a cytolytic event between human peripheral blood monocytes and Raji cells coated with C3b, antibody, or both. Presence of $\mathrm{C} 3$ was confirmed by immune adherence. IgG bound to the Raji membrane was quantitated using $I^{125}$ Staphylococcal protein $A$ assay. The presence of alternate pathway-activated $\mathrm{C} 3$ on Raji cells failed to produce monocyte-mediated cytotoxicity. These same target cells subsequently coated with antibody concentration ranging from 200 to $>600,000$ SPA molecules per Raji cell produced neither enhancement nor inhibition of antibody-dependent, cell-mediated cytotoxicity (ADCC). ADCC was enhanced by complement when complement activation and binding of $\mathrm{C} 3$ to the cell surface occurred by classical pathway mechanisms. ADCC of $32 \% \pm 3.2$ occurred with undiluted antiserum $(625,000$ SPA molecules bound/Raji cell) with enhancement to $52 \% \pm 1.1$ in the presence of $\mathrm{C} 3$. IgG inhibition of ADCC was unaffected by the presence of membrane-bound C3.
\end{abstract}

\section{INTRODUCTION}

Peripheral blood monocytes are the precursors of tissue macrophages and possess membrane receptors for the $\mathrm{Fc}$ region of $\mathrm{IgG}$ immunoglobulin (Fc receptor) and the third component of complement (C3) (1). The Fc receptor allows these cells to interact with antibody-coated red cells (2) and tumor cells (3) resulting in target cell damage and lysis. This reaction has been termed antibody-dependent, cellular cytotoxicity (ADCC) and several cell types which bear membrane Fc receptors can act as effector cells, i.e., granulocytes (4), monocytes (5), and K lymphocytes $(6,7)$. The $\mathrm{C} 3$ receptor has been shown to be important in the ingestion of bacteria and other particles by granulocytes and macrophages (8). In addition, cells possessing the $\mathrm{C} 3$ receptor have the ability to bind or attach to C3-coated target cells (9). However, it is unclear whether this C3 receptor can trigger leukocyte-mediated, target cell damage and lysis.

\footnotetext{
${ }^{1}$ This work was supported by NCI Grant R01 CA25641-02. Howard B. Kessler was supported by Roessler Foundation funds, Ohio State University.

${ }^{2}$ Address all correspondence to Dr. A. F. LoBuglio, Simpson Memorial Research Institute, 102 Observatory Rd., Ann Arbor, Mich. 48109.
} 
Several studies have examined the interaction of lymphocytes with C3-coated, red cell targets and failed to demonstrate target cell damage $(10,11)$. However, Scornik has suggested that the lymphocyte $\mathrm{C} 3$ receptor may play a role in target cell lysis by preventing inhibition of ADCC by soluble immunoglobulin when target cells are coated by both IgG immunoglobulin and C3 (12). Kurlander has examined the interaction of blood monocytes with red cell targets coated with IgG immunoglobulin and/or C3 (13). They concluded that $\mathrm{C} 3$ on the target cell surface can enhance ADCC but not mediate cytolysis directly.

No information exists on the role of $\mathrm{C} 3$ on tumor cell targets in regard to mediating cytolysis by monocytes or macrophages. We have chosen to examine the interaction of monocytes and tumor cells (Raji) coated with $\mathrm{C} 3$ in the presence or absence of cell-bound antibody. This B-cell lymphoblast cell line was chosen because it is capable of activating the alternate complement pathway resulting in C3-coated tumor cells independent of antibody $(14,15)$.

\section{METHODS}

\section{Effector Cells}

Purified suspensions of blood monocytes were obtained from normal healthy donors as previously described (3). Briefly, mononuclear cell preparations obtained by Ficoll-Hypaque density centrifugation (16) were washed twice in RPMI-10\% fetal calf serum (FCS) and resuspended to a concentration of $15 \times 10^{6} /$ mononuclear cells $/ \mathrm{ml}$. The 5-ml aliquots were added to Falcon 3003 tissue culture dishes and incubated for $90 \mathrm{~min}$ at $37^{\circ} \mathrm{C}$ in a humidified $95 \%$ air $-5 \% \mathrm{CO}_{2}$ atmosphere. These dishes were vigorously washed five times with RPMI-10\% FCS to remove nonadherent cells. The adherent cells were exposed to ice cold $\mathrm{Ca}^{2+}$ - and $\mathrm{Mg}^{2+}$-free buffer containing $0.2 \%$ bovine serum albumin and $0.1 \%$ EDTA for $30-45 \mathrm{sec}$ at which time the adherent cells were gently removed from the surface using a rubber policeman. These cells were then washed three times in RPMI-0.5\% human serum albumin. Viabilities exceeded $90 \%$ by trypan blue exclusion and were greater than 95\% pure using latex ingestion, nonspecific esterase, and morphology as critcria.

\section{Target Cells}

Raji, a human B lymphoblastoid cell line derived from an individual with Burkitt's lymphoma (17) was cultured in RPMI-10\% fetal calf serum supplemented with $0.3 \mathrm{mg} / \mathrm{ml} \mathrm{L}$-glutamine, $0.1 \mathrm{mg} / \mathrm{ml}$ gentamicin, and $100 \mathrm{units} / \mathrm{ml}$ penicillin. Raji cells were consistently used 48 to $72 \mathrm{hr}$ after splitting of the culture and cell viabilities were always greater than $90 \%$ by trypan blue exclusion. The target cells were labeled with ${ }^{51} \mathrm{Cr}$ (sodium chromate, New England Nuclear) as previously described (3).

These cells were treated in a variety of ways to produce four different types of target cells. First, Raji cells coated with $\mathrm{C} 3$ alone via alternate pathway activation $(14,15)$ were prepared by incubation of $3 \times 10^{6}$ cells with $60 \mu \mathrm{l}$ of normal fresh serum or C-6-deficient serum (generously provided by Dr. Terrence Lee, Department of Medicine, University of North Carolina Medical School) for $\mathbf{2 0}$ min at $37^{\circ} \mathrm{C}$. This dose of sera and time of incubation were selected by preliminary studies which demonstrated $<10 \%$ lysis (due to complement fixation) and strongly 
positive immunoadherence assays. In general, the C-6-deficient sera gave stronger immunoadherence and less lysis of Raji cells. A second type of target cell was coated with antibody alone by incubating $10 \times 10^{6}$ Raji cells with $100 \mu$ l of heat-inactivated immune rabbit antisera (3) or with $100 \mu \mathrm{l}$ of several log dilutions of such antisera at $37^{\circ} \mathrm{C}$ for $45 \mathrm{~min}$. The cells were washed and then ready for assay. A third target were Raji cells coated with C3 by alternate pathway activation (as above) and then coated with antibody by incubation with rabbit immune sera (or dilutions of immune sera). Finally, a fourth target preparation involved incubation of Raji cells with rabbit immune sera (as above) followed by incubation with the C-6-deficient serum $\left(60 \mu \mathrm{l} / 3 \times 10^{6}\right.$ cells at $37^{\circ} \mathrm{C}$ for $\left.20 \mathrm{~min}\right)$ which would allow $\mathrm{C} 3$ attachment via classic pathway as well as alternate pathway. In all instances, the presence of $\mathrm{C} 3$ on the Raji cell surface was confirmed by immune adherence (IA) assay (15) and by reactivity with immunobeads coated with rabbit antihuman C3 (Bio-Rad Laboratory, Richmond, Colo.). Control target cells included cells incubated in media alone or in heat-inactivated normal serum.

\section{Microcytotoxicity Assay}

Cytotoxicity assays were carried out as previously described (3) in Falcon 3040 microtest II tissue culture plates. Triplicate cultures of 200,000 monocytes were co-incubated with 20,000 target cells (effector: target ratio of 10:1) in a final volume of $300 \mu \mathrm{l}$ (RPMI-1640 with 10\% FCS). Triplicate cultures of target cells alone were used to determine spontaneous release of ${ }^{51} \mathrm{Cr}$. The microtest plates were centrifuged at $60 \mathrm{~g}$ for $4 \mathrm{~min}$ to initiate effector-target-cell interaction, and then incubated at $37^{\circ} \mathrm{C}$ in a humidified atmosphere of $95 \%$ air $-5 \% \mathrm{CO}_{2}$ for $4 \mathrm{hr}$. At the end of $4 \mathrm{hr}, 100 \mu \mathrm{l}$ of the supernatant was removed from each well to determine total supernate cpm (by multiplying $\times 3$ ). Percentage cytotoxicity was calculated by the formula:

$$
\% \text { cytotoxicity }=\frac{\mathrm{A}-\mathrm{B}}{\mathrm{C}} \times 100,
$$

$A=$ mean $\mathrm{cpm}$ in supernate of wells containing target cells and monocytes, $\mathrm{B}=$ mean $\mathrm{cpm}$ in supernate of wells containing target cells alone, and $\mathrm{C}=$ mean total cpm of target cells added to each well.

\section{Determination of Immunoglobulin Bound to the Raji Cell Surface}

Quantitation of cell-bound antibody was assessed using I $^{125}$-labeled Staphylococcal protein A (SPA), a 42,500 molecular weight protein known to bind specifically to the $F_{c}$ portion of $\operatorname{IgG}$ globulin $\left(\operatorname{IgG}_{1,2,4}\right)$ in man (19). Duplicate aliquots of $1 \times 10^{6}$ cells were incubated with an excess $(50 \mathrm{ng})$ of $\mathrm{I}^{125}$-labeled SPA for $60 \mathrm{~min}$ at $25^{\circ} \mathrm{C}$. The cells were then washed three times to remove unbound SPA. The counts per minute (cpm) bound to the cells were used to calculate the number of SPA molecules bound/cell as a quantitation of membrane-bound immunoglobulin. Prior studies indicated that 0.5-2 molecules of SPA bind/molecule IgG (19).

\section{Experiments to Characterize the Role of Complement on IgG Inhibition of ADCC}

We examined the competitive inhibition of ADCC by human immunoglobulin (purified human IgG, Miles Laboratory, Elkhart, Ind.) as previously described (3). 
Appropriate concentrations of IgG were added to microwells containing monocytes and preincubated at $37^{\circ} \mathrm{C}$ for $30 \mathrm{~min}$. Various types of target cells were then added and the assay was carried out in the usual fashion.

\section{RESULTS}

\section{The Effect of Alternate Pathway Activated Complement of Monocyte-Tumor-Cell Interaction}

As illustrated in Fig. 1, incubation of monocytes with Raji cells coated with C3 via alternate pathway activation produced no more $\mathrm{Cr}^{51}$ release than seen with control Raji cell preparations. This observation was true whether fresh normal or C6-deficient sera was used as a source of complement components. In addition, preparation of Raji cells coated with $\mathrm{C} 3$ via alternate pathway followed by sensitization with rabbit antisera produced no greater monocyte-mediated cytolysis than that seen with tumor cells coated with antibody alone (Fig. 1). In order to examine the effect of $\mathrm{C} 3$ on a broad range of antibody concentration on the cell surface, we sensitized the Raji cells following C3 attachment with serial $\log$ dilutions of our rabbit antisera. Figure 2 illustrates the broad range of cell-bound antibody which results from this type of antisera dilution as quantitated by the $\mathrm{I}^{125}$ SPA radioimmunoassay for cell-bound antibody. As can be seen, the range of SPA molecule binding extends from $600,000 /$ cell (undiluted antisera) to $240 /$ cell $\left(10^{-6}\right.$

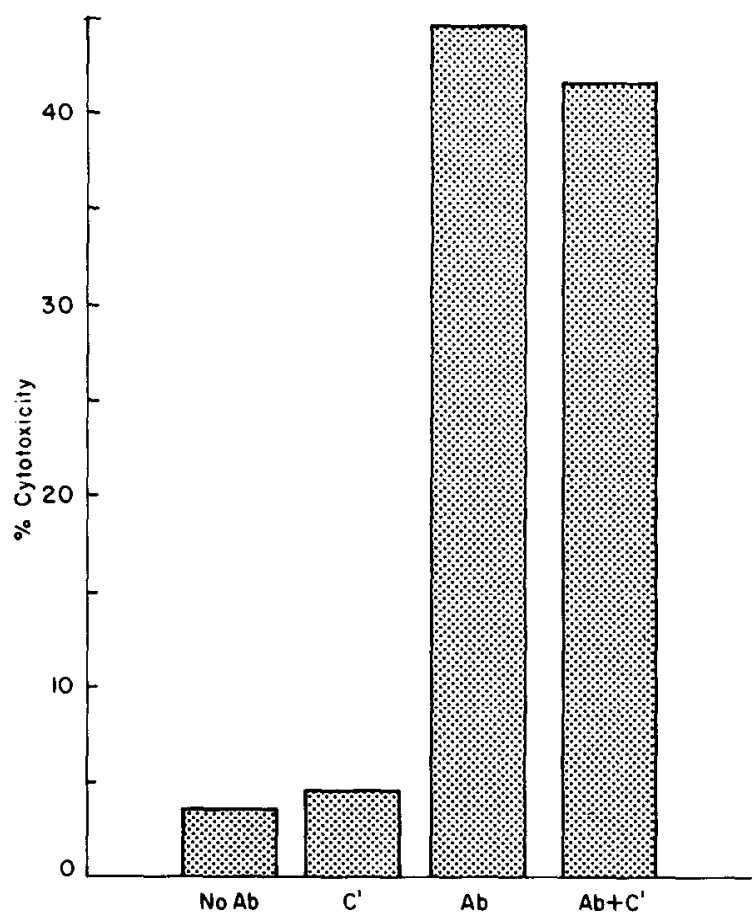

FIG. 1. Effect of alternate pathway activated C3 on Raji cell interaction with monocytes. Monocyte mediated lysis of Raji lymphoblasts (no Ab), complement-coated Raji ( $\left.C^{\prime}\right)$, Raji cells sensitized with rabbit antiserum (Ab), and Raji cells initially treated with $\mathrm{C6}$-deficient serum and subsequently sensitized with heat-inactivated rabbit antiserum $\left(A b+C^{\prime}\right)$. 




FIG. 2. The effect of antiserum dilution on Raji-bound IgG. Raji cells sensitized with logarithmic dilutions of antiserum and subsequently assessed for membrane-bound IgG in terms of number of molecules of radiolabeled SPA bound/target cell.

dilution of antisera). Figure 3 illustrates that the degree of ADCC correlates with the degree of antibody sensitization and that the presence of $\mathrm{C} 3$ activated by alternate pathway does not alter the cytotoxicity seen with antibody alone. Again, Raji cells coated with $\mathrm{C} 3$ alone failed to result in significant degrees of cytolysis.

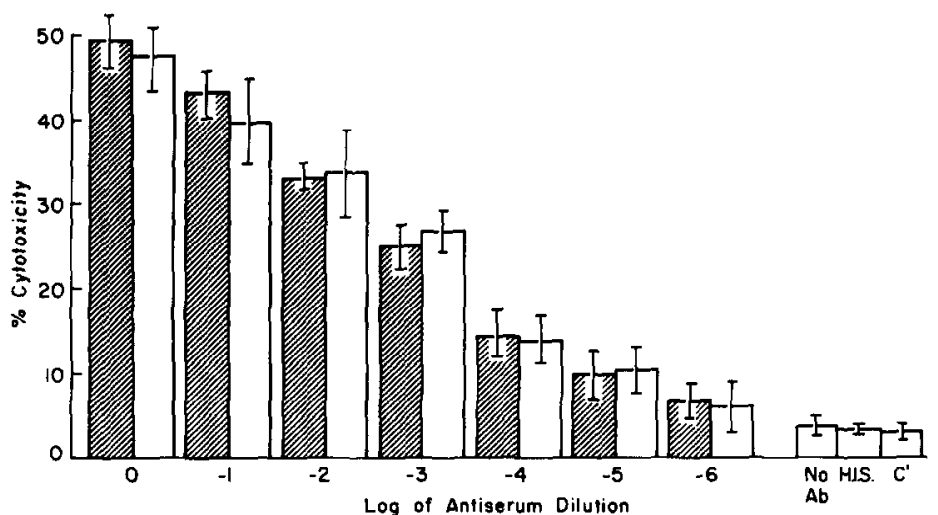

FIG. 3. The effect of alternate pathway activated complement on ADCC. Raji cells incubated with C6-deficient serum and then sensitized with varying dilutions of antiserum (open bars) were compared with Raji which were incubated with antiserum but not C6-deficient serum (hatched bars). Controls include Raji cells which were incubated with media alone (no Ab), heat-inactivated serum (HIS), and C6-deficient serum $\left(C^{\prime}\right)$. 


\section{Effect of Complement Activated via Classical Pathway on Monocyte ADCC}

In order to examine the effect of Raji cell-bound C3 activated via the classical pathway, cells were sensitized with varying dilutions of antibody and then incubated with C6-deficient serum as a source of complement components. Immune adherence assays for $\mathrm{C} 3$ were positive at all serum dilutions illustrated in Fig. 4. As can be seen in Fig. 4, the presence of $\mathrm{C} 3$ on the cell surface enhanced ADCC when target cells were sensitized with undiluted antisera, i.e., $32 \% \pm 3.2$ to $52 \% \pm 1.1(n=3 ; P<0.01)$. No enhancement was seen with sensitization of Raji cells at lower dilutions of antisera (target cells IA positive at all dilutions of antisera).

These experiments were carried out 3 months after those illustrated in Fig. 3 and the lower degree of ADCC produced by the antisera is unexplained. Measurement of IgG-bound/Raji cell was identical to the curve illustrated in Fig. 2 so that change in degree of antibody sensitization does not account for the lower degree of ADCC.

\section{Effect of $C 3$ on $\mathrm{Ig} G$ Inhibition of $A D C C$}

In order to determine whether the presence of $\mathrm{C} 3$ on the Raji cell surface could enhance monocyte-target-cell interaction which occurs during ADCC, we examined the effect of cell-bound $\mathrm{C} 3$ on the ability of soluble immunoglobulin to inhibit ADCC (3). As seen in Table 1, enhancement of cytolysis is seen when $\mathrm{C} 3$ is present on the Raji cell surface via classical pathway activation with undiluted antisera. However, no dramatic change occurred in the ability of soluble IgG to cause competitive inhibition of the ADCC reaction. Thus, comparable degrees of inhibition were seen with 1 and $10 \mathrm{mg} / \mathrm{ml}$ soluble IgG whether the target cells were coated with antibody and C3 or antibody alone. This was also true for IgG inhibition over the whole range of antisera listed in Fig. 4 (data not shown).

\section{DISCUSSION}

The presence of the third component of complement on the surface of various targets (bacteria and red cells) certainly plays an important role in phagocytosis of

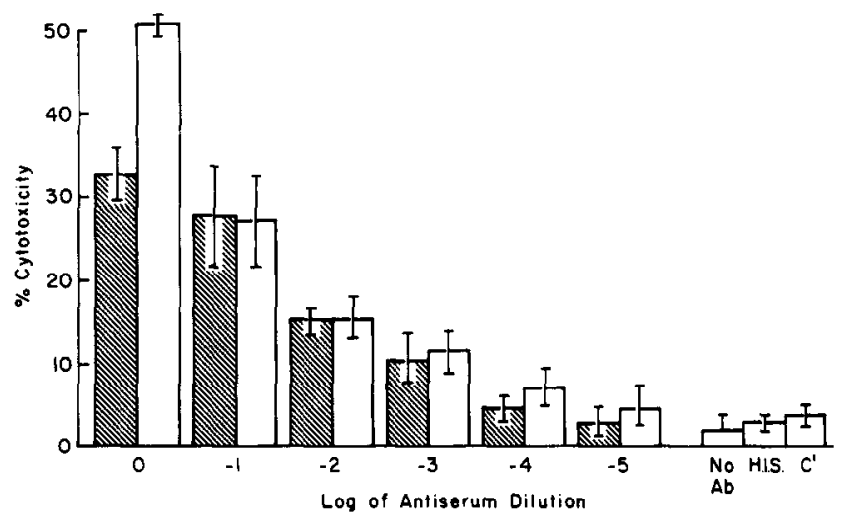

FIG. 4. The effect of complement activated by classical pathway on ADCC. Raji targets initially sensitized with logarithmic dilutions of rabbit antiserum (hatched bars) were compared to similar targets subsequently exposed to C6-deficient serum (open bars). Controls are identical to those in Fig. 3. 
TABLE 1

Effect of $\mathrm{C} 3$ on IgG Inhibition of Monocyte $\mathrm{ADCC}^{n}$

\begin{tabular}{ccccc}
\hline & & \multicolumn{3}{c}{ IgG concentration (ng/ml) } \\
\cline { 3 - 4 } & Targets $^{b}$ & 0 & 1 & 10 \\
\hline \multirow{2}{*}{ Expt 1 } & T & 3.9 & 4.7 & 5.6 \\
& T-A & 36.5 & $19.7(46)$ & $4.8(87)$ \\
& T-A-C & 51.2 & $25.8(50)$ & $14.9(71)$ \\
& T & 4.1 & 6.1 & 5.2 \\
& T-A & 33.8 & $15.6(54)$ & $6.2(82)$ \\
& T-A-C & 47.7 & $22.0(54)$ & $13.6(71)$ \\
\hline
\end{tabular}

${ }^{a}$ Values listed represent percentage cytotoxicity. The values in parentheses reflect the percentage inhibition of ADCC.

${ }^{b}$ (T) Raji lymphoblasts, (T-A) Raji sensitized with undiluted antiserum, (T-A-C) Raji sensitized with undiluted antiserum followed by incubation with $\mathrm{C} 6$-deficient serum.

such targets by granulocytes and monocytes $(8,9,13)$. These effects are thought to be mediated by a membrane receptor for $\mathrm{C} 3$ on the surface of granulocytes and monocytes which can mediate binding of $\mathrm{C} 3$-coated targets to the effector cell surface $(1,9)$. However, it is unclear whether this membrane receptor can mediate or trigger effector cell damage of bound but not ingested target cells. Several studies have examined red cell targets coated with $\mathrm{C} 3$ and were unable to demonstrate cytolysis by lymphocytes $(10,11)$ or monocytes (13). Our studies utilizing C3-coated lymphoblast target cells have similarly failed to demonstrate cytolysis by monocytes as well as human lymphocyte preparations (unpublished observations).

A second role for the $\mathrm{C} 3$ receptor has been proposed in that it may act in concert with effector cell receptors for immunoglobulin and thus enhance the lytic potential toward red cell targets coated with IgG immunoglobulin and complement $(10,11$, 13). Indeed, we found definite enhancement of $A D C C$ when $C 3$ was activated on the target cell surface by large numbers of IgG although smaller amounts of antibody or binding of $\mathrm{C} 3$ by the alternate pathway of complement activation produced no change in ADCC.

Finally, the $\mathrm{C} 3$ receptor has been reported to aid in cytolysis of red cells coated with antibody and $\mathrm{C} 3$ by preventing inhibition of lysis by competing immunoglobulin (12). We were unable to demonstrate this effect even using target cells coated with $\mathrm{C} 3$ to a degree which enhanced the ADCC event.

Thus, our studies on the interaction of monocytes with $\mathrm{C} 3$-coated tumor cells are in keeping with several observations made using red cell targets in that we were unable to demonstrate direct cytolysis of targets coated with $\mathrm{C} 3$ alone and some enhancement of ADCC when C3 was present in optimal fashion. However, the lack of effect of $\mathrm{C} 3$ alone should be interpreted with caution. This could also reflect a quantitative or qualitative limitation of our ability to place $\mathrm{C} 3$ on the cell surface in the absence of IgG immunoglobulin. For example, several lymphoblast cell lines are capable of triggering the alternate pathway of complement activation and deposition of $\mathrm{C} 3$ on the surface of Raji cells is thought to be, at least in part, due to the presence of $C 3$ receptor on the Raji cell surface $(14,15)$. Thus, the orientation of the C3 molecule present may be less than optimal for subsequent interaction with the 
monocyte $\mathrm{C} 3$ receptor despite the fact that these cells are strongly immune adherence positive. Similarly, the lack of C3 enhancement of ADCC at low dilutions of antisera may relate to quantitative changes in the amount of $\mathrm{C} 3$ on the target cell surface despite the fact that the cells were IA positive.

\section{REFERENCES}

1. Huber, H., Polley, M. J., Linscott, W. D., Fudenberg, H. H., and Muller-Eberhard, H. J., Science 162, 1281, 1968.

2. LoBuglio, A. F., Cotran, R. S., and Jandl, J. H., Science 118, 1582, 1967.

3. Shaw, G. M., Levy, P. C., and LoBuglio, A. F., I. Clin. Invest. 62, 1172, 1978.

4. Gale, R. P., and Zighelboim, J., J. Immunol. 118, 567, 1975.

5. Shaw, G. M., Levy, P. C., and LoBuglio, A. F., J. Immunol. 121, 573, 1978.

6. Nelson, D. L., Bundy, B. M., Pritchon, H. E., Blaese, R. M., and Strober, W., J. Immunol. 117, $1472,1976$.

7. Malewicz, F. M., Shore, S. L., Ades, E. W., and Phillips, D. J., J. Immunol. 118, 567, 1977.

8. Griffin, F, M., In "Biological Amplification Systems in Immunology" (N. K. Day and R. A. Good, Eds.), pp. 90-91. Plenum, New York, 1977.

9. Ehelenberg, A. C., and Nussenzweig, V., J. Exp. Med. 145, 357, 1977.

10. Perlmann, P., Perlmann, H., and Muller-Eberhard, H. J., J. Exp. Med. 141, 287, 1975.

11. Van Boxel, J. A., Paul, W. E., Green, I., and Frank, M. R., J. Immunol. 112, 398, 1974.

12. Scornik, J. C., Science 192, 563, 1976.

13. Kurlander, R. J., Rosse, W. F., and Logue, J., J. Clin. Invest. 61, 1309, 1978.

14. Theophilopoulos, A. N., and Perrin, L. H., J. Exp. Med. 143, 271, 1976.

15. Budzko, D. B., Lachmann, P. J., and McConnell, I., Cell. Immunol. 119, $1195,1977$.

16. Böyum, A., Scan. J. Clin. Lab. Invest. 21(Suppl. 97), 77, 1968.

17. Puluertaft, R. J. V., J. Clin. Pathol. 18, 261, 1965.

18. Bruner, K. T., Ingers, H. D., and Cerrottini, J. C., In "In Vitro Methods in Cell Mediated and Tumor Immunity" (B. R. Bloom and J. R. David, Eds.), p. 423. Academic Press, New York, 1976.

19. Dorval, G., Welsh, K. E., and Wigzell, H., J. Immunol. Methods 7, 237, 1975.

20. Ross, G. D., Polley, M. J., Rabellino, E. M., and Grey, H. M., J. Exp. Med. 138, 798, 1973. 